\title{
The Particularity of Prehistoric Culture in Vlora Region (Albania)
}

\author{
Aleks Trushaj \\ Ermal Sina \\ Ismail Qemali Vlora University \\ Email: alekstrushaj@gmail.com
}

Doi:10.5901/ajis.2014.v3n4p49

\begin{abstract}
Vlora area is lying to the southwest of Albania, it also carries a wealth of archaeological sites of all periods and in particular it is characterized by specific archaeological site of prehistoric culture, the particularities of which are rare in our country, in Balkan and Europe. By the given observations, research, documentation and comparisons, we have been able to distinguish this area from the others in terms of specific elements of the locality contains prehistoric culture. In this region is proved that Paleolithic human activity in the early phase of this era which has been lacking in prehistoric archaeological central sites of our country. In the area of Vlora, there is the only evidence in the form of a megalithic stone table (Dolmen) in village of Vranisht. AtVelça village we have large complex natural karst caves used for housing by primitive man during the Neolithic era. In Lepenica village of Vlora, there is the largest rock painting in our country and more specific in terms of its composition compared less with other site in Europe in terms of prehistoric scope. This art shows us for the ancient beliefs, for life, for real-world perception of the creators of this imaginary rock painting. The region of Vlora has no cultural gap, it contains all the archaeological and historical periods.
\end{abstract}

Keywords: Archaeological site; prehistoric culture, megalithic construction; Neolithic period; rock paintings; anthropomorphic figures.

\section{Introduction}

Vlora district is positioned in southwestern Albania with a northwest-southeast extension. In the east is restricted by Tepelena district, in the southeast by Gjirokastra district, in south and southeast by Saranda small coastal city, in the southwest and west by the Adriatic and Ionian Sea, bordered to the north with the district of Fier by visible natural boundaries of river Vjosa. (Ancient Aoosi). In the south and east is rugged mountainous terrain, north-northwest and west terrain is flat with two territorial units;

These are Vlora Bay, Myzeqe lowland. Vlora territory Inland since VItth century B.C started life Amantia ancient city (Ploce country) followed by Olympe (Mavrova country) and the town of Cerja in Mesaplik village. In Vlora Bay within ancient time four cities and towns flourished as Oriku, Thronioni (Kanina), Triporti and Aulona. The region has been inhabited since the early stages of prehistory, thus is characterized by archaeological site of prehistoric culture, features of which are rare in Albania, in the Balkans and Europe (figure. 1). 


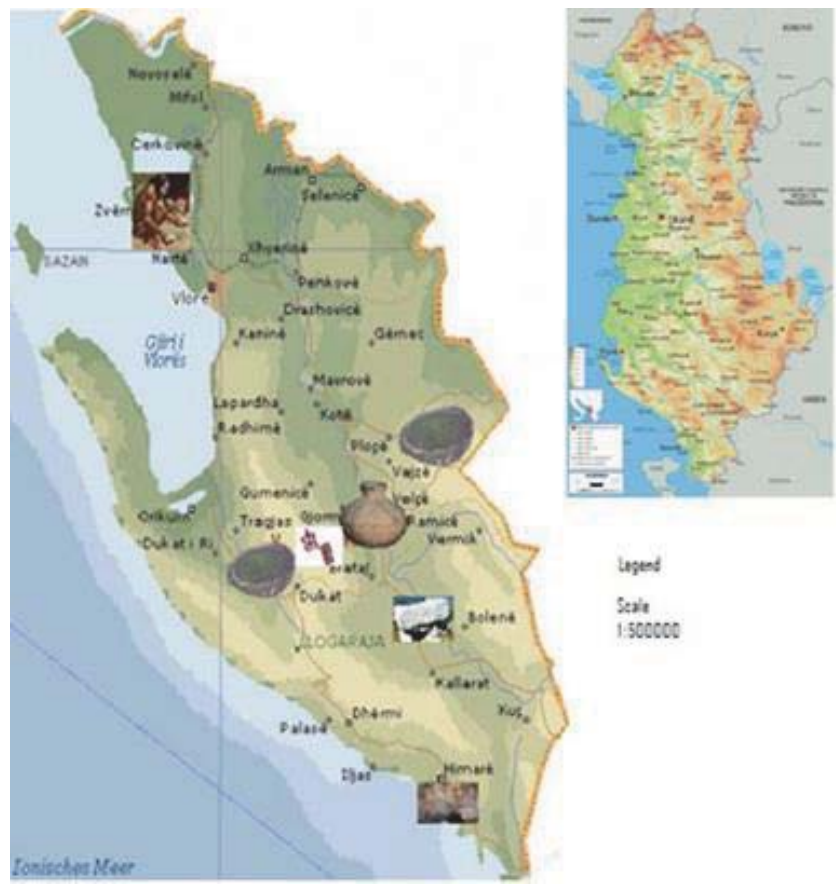

Figure 1. Prehistoric center in Vlora District

Archeological sites Site that separate Vlora region, characterized from a complex archaeological heritage, historical, ethnographic and linguistic one.

Particularly are distinguished two areas; coastal areas or "bay" and the upper area that encompasses the villages raised on both sides of the river Shushica. This part of the valley is bordered on the left by Shushica flow and by Lungara - Çika Mountains, while on the right by Kurveleshi and Griba mountains.

\section{Research Methodology}

Achieving the goal material are being used several methods of study, such as surveys based on territory Velça village caves and Zvernec coastal area, measurements and photographs taken there as in written cave Lepenica, performed in cooperation with the archaeologist M.Korkuti.

The research, excavations and collections of objects on the ground, as well as in Treport and Dajlani coastal area (base shore) are made in collaboration with archaeologists M.Korkuti, N.Barjami, E.Sina etc. Meanwhile about Zverneci area through stratigraphic method in collaboration with geologist L. Hasani is made the Paleolithic difference layer from other subsequent periods.

\section{Findings and Discussion}

Vlora region is distinguished from the others in terms of the specific elements of prehistoric culture that it contains. In this region has been testified the Palaeolithic human activity, that in the early phase of this era ranging from 1.5 million years ago to 200 thousand years, which has been lacking in prehistoric archaeological sites of our country. Zverneci Paleolithic station is the most special in our country, because it satisfies prehistoric cultural gap of the earliest Paleolithic stage. In the upper zone of Shushice we have the only megalithic evidence in form of a stone table (Dolmen) Vranisht village.

A huge complex of karst cave used for housing during the Neolithic epoch makes the archaeological site of Velca village the most seldom one in the world. A Neolithic cave habitat we have in Spile of Himara country. Numerous caves and mountains are found in Karaburun peninsula and Llogara mountains (The antique Akrokeraune) as Haxhi Aliu Cave, John Duke Cave, Gjidhime Cave etc. The Neolithic culture cave is found in the whole territory of our country, as in the 
Balkans, Europe and the world, but Velça case is really different because after a rocky arc in a length of a kilometer there are twelve caves which served as a residence for prehistoric human life. The upper zone of Shushica, Lepenica village, is found the biggest rock paintings in our country and the most particular one, with regard to its composition with little comparisons of other site in Europe, including the field of prehistoric art.

These paintings are realized in a shelter of cave, that's why locals know it as the "Shpella e Shkruar" (Written Cave).Vlora zone is not lacking evidences of culture from metals epoch such a small burial mound Tombs of bronze-iron in villages, Mallkeq, Vajze, Dukat and Tragjas there is no cultural gap in region of Vlora, it contains all the archaeological and historical periods. The territory of Vlora has attracted the attention of foreign scholars as archaeologists, historians, geographers, botanist, etc. Starting point for the study of prehistoric and ancient culture research have marked the archaeologists as Treger (P.Treger, 1903) (P.Treger, 1903), K.Pac (C.Ptsch, 1904) (C.Ptsch, 1904), L.M.Ugolini (L.M.Ugolini, 1927)(L.M.Ugolini, 1927)and especially Cardin's research, in the field of prehistory and especially the Velça cave dwellings.

In 30 years an Italian archaeological expedition led by Kardini first undertook research to delve into the prehistoric valley of Shushica exploring the rocky area of Velca Village and in particular in the Cave of Skotes. (Skote-darkness)

Nowadays, the region contains many prehistoric settlements, but the uniqueness of this culture nowadays lies in archaeological monuments without recurring such as; megalithic monument in the village of Vranisht (IV-th millennium B.C), the settlements system of Neolithic cave habitat of village Velca, rocky cave paintings in Lepenica village, and, since 2011, after a survey made by archaeologists M.Korkuti and A.Trushaj, we can say that it was discovered the great Palaeolithic station in our country, in Zvernec - Vlora region, with a significant presence of early Palaeolithic findings, part of which is present for the first time in this paper.

\subsection{Paleolithic residence of zverneci}

Hill in northern coastline of Treportit in a zone comprising the lighthouse zone (figure 2.a) and continues until Dajlan (figure 2.b) has proved the existence of a Paleolithic coastal settlement large enough not much from the extent than the large amount of objects made of stone exploited by flint stone of Paleolithic tribes have used geo-climate conditions of the area and have lived in the same place throughout the Paleolithic era up to the $\mathrm{X}$ millennium $\mathrm{BC}$.

This tribe moved through the area in search of food by controlling a territory of $30-40 \mathrm{~km}$ radius. This finding proves the nuclei of flint in the township, formations which are found only in the area of Karaburun , or Lungare, Llogara. Nuclei used are yellow, gray, dark brown.

Near seaside in this area is a layer of soil with reddish brown thing that corresponds to the characteristics of Paleolithic cultural layer (figure 2.b). The Paleolithic settlement habitat contains multiple tools from the Paleolithic flint stone as wedges, scraper, drilling, cutting, ripper, flint stone knives, where particular value stand on those of early Paleolithic epoch (figure 3).

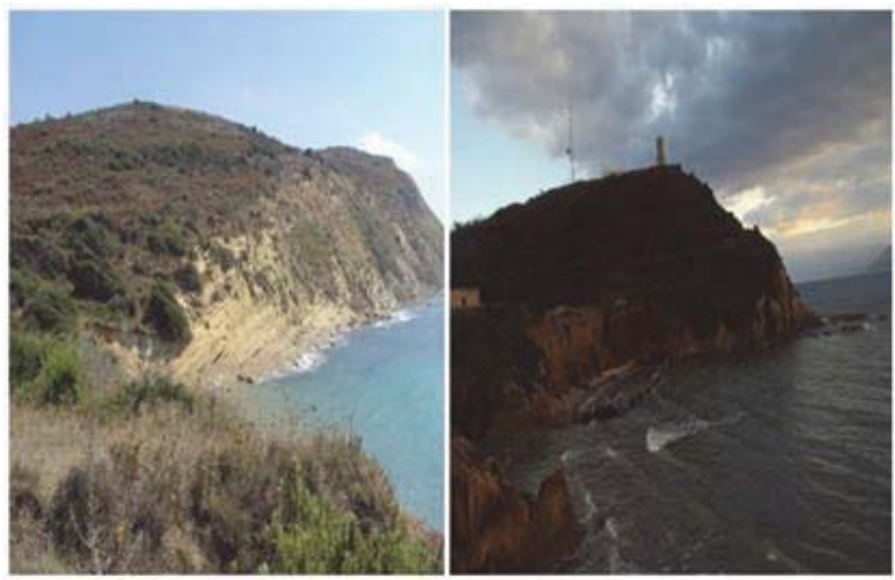

Figure 2a. (Photo by A.Trushaj), Treporti

Figure 2b. (Photo by A.Trushaj), Dajlani 


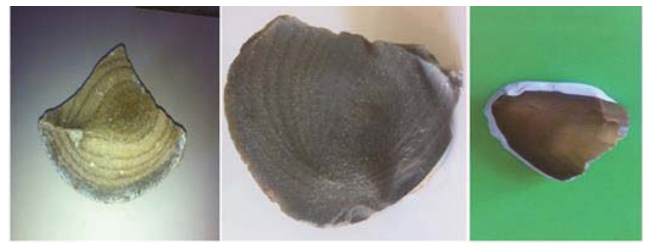

Figure 3.a. (Photo by E.Sina), Nuclei found in residence of Zvernec

\subsection{The Megalith of Vranisht}

It's a rare act of prehistoric architecture dedicated to sun worship. His location is in ridge of Mount Lipe that is part of the Cika ( Akrokeraune) that this name in Albanian means ( Cika ) - (sparks), sparks, flames and a knowledgeable antique sayings that Zeus struck with lightning in the mountains Keraune and the surroundings.

He is like a table of two rocky foot $3 \mathrm{~m}$ distance from each other to $2 \mathrm{~m}$ high and is placed above a large slab of rock more or less square (figure 4). Its usage has become a cult object that in the fourth millennium BC this megalith (Dolmen) served as the altar of the shrine's natural that is frequented by prehistoric man. His recognition by locals as the "Stone of Heaven ", or "The Lord dining", shows that he has been an important part of religious ceremonies since the prehistory. Megalith is not the work of a human hand but his appearance has attracted prehistoric man to develop dedications and sacred ceremonies.

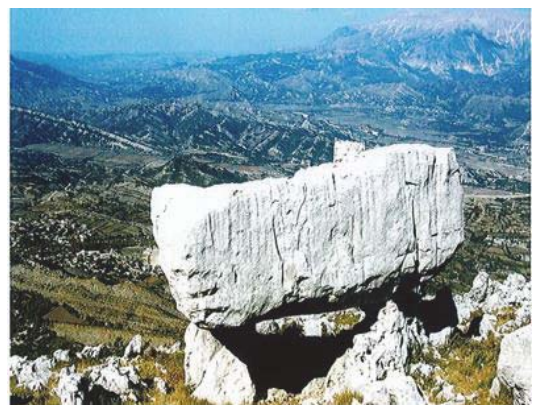

Figure 4. (Photo by A.Trushaj), Photo of megalith in Vranisht village

\subsection{Velça Caves}

Velça area is characterized by carbonate geological layers; this has made possible the rapid development of karst phenomena resulting in creation of many natural caves which were used as dwellings (habitat) of Neolithic period (figure5)

Based on previous research, the latest explorations of the cave Ligaces and observations in several other caves (Cave of Presarani) we can say that Velca remains the largest station of natural caves inhabited by the human of the new stone-age.

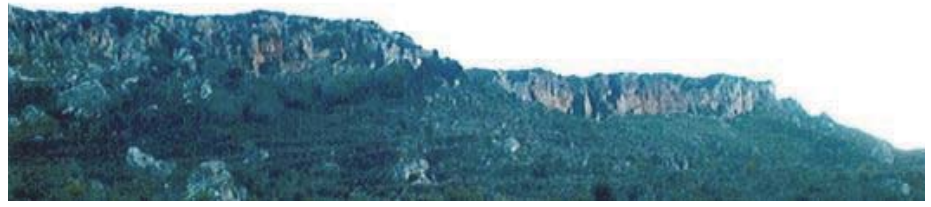

Figure 5. (Photo by A.Trushaj), Rocky range where there are caves in the village of Velca 
In the cave of Skota (figure 6.a,b), a cave with two floors with this view from the south, found a hearth fire, knives, needles of bone, stone hammers and pottery in brown, red, black decorated geometric figures.
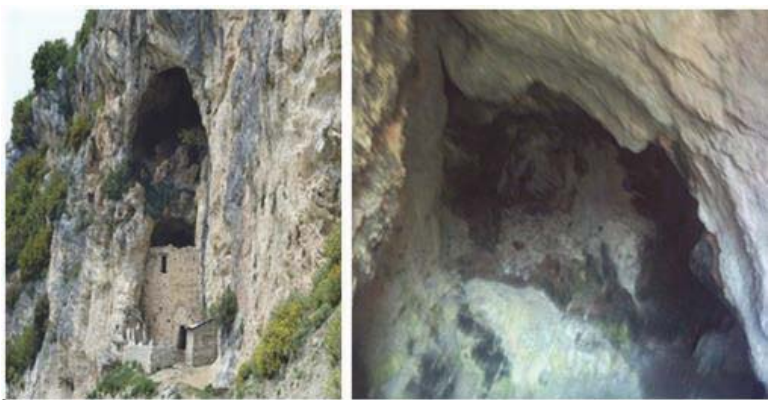

Figure 6.a.( Photo by A.Trushaj), Skote's cave Figure 6.b.( Photo by A.Trushaj), The entrance of Skote's cave

This potter has similarities to that detected in Maliq I, which belongs to the late Neolithic period and Eneolithic era (copper age). These findings made by Prof.Kardini belong to the IV millennium B.C. They were commented by Italian professor Marconi, who notes: "This is Neolithic culture spread across the central valley of the Danube, in the Central Region and the Balkan Peninsula. It is found also in southern Italy, especially in Apulia, and the question may be how widespread these similarities in such areas are so disconnected from each other apparently is explained, that Albania is the link that connects it with the Italian Peninsula Balkan " (D.Mustil, 1954-1955) (D.Mustil, 1954-1955)

Recent discoveries of Paleolithic culture in the village of Zverneci are testifying that prehistoric man was present in this region earlier than the time of new stone. Cave offers many touristic opportunities. Its two floors pose no difficulties for visitors. It extends west entrance with a narrow tunnel along $20 \mathrm{~m}$ which leads to the upper floor of the cave. Prehistoric Culture of Velça is not linked only by a cave, so a good opportunity to identify more clearly what remains of Presarani caves, or the "Loom", as locals call it, overlooking the north, against Skote cave. The cave has an entrance about $20 \mathrm{~m}$ high from the ground, making it difficult to introduce in; near the entrance stands a higher walls around $1 \mathrm{~m}$ and my $2 \mathrm{~m}$, build with plates, placed one above the other in relation to dry, possibly to prevent children overthrow (figure7).

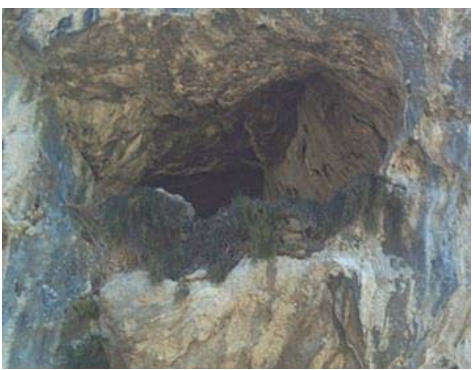

Figure 7. (Photo by A.Trushaj), Presarani 's cave, "The loom"

In all the territory of Velça are found about 20 caves with residential opportunities as Maci caves, Ligace cave, cave of Trubull etc. Velca remains indisputably the largest archaeological site of Neolithic cave culture. The discovery of a new Paleolithic station in the village Zvernec adds us confidence that we should evolve searching in Velca village for a prehistoric culture of the earliest Neolithic it.

\subsection{The painting of the Written Cave}

The cave is located at the height of $800 \mathrm{~m}$ from sea level in the north-eastern slope of the summit of the Keramenges $(1837 \mathrm{~m})$ which is the northern tip of the Lungare ridge (figure 8$)$, which finishes the south tip of Brati. The two peaks are separated by each other by tectonic fractures. 


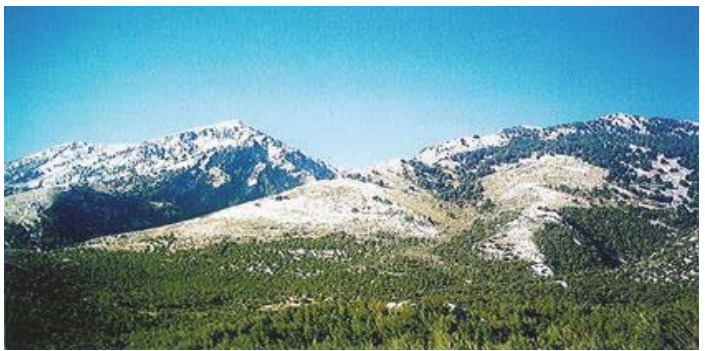

Figure 8. ( Photo by A. Trushaj), On the right the top of Keramenga.

The paintings are realized in the ceiling of a cave shelter from high ground about 3 meters but a groundsel of $2 \times 2.5 \mathrm{~m}$ size creates opportunities to touch the ceiling of the porch with hand being in the sitting position (Figure 8). On this groundsel or fire light table, baked meat and are more protected from the hot sun or heavy rains. Prehistoric man has been very easy to realize a rocky art which testify the efforts of people in order to identify their existence, their activity, perception of real and imaginary world.

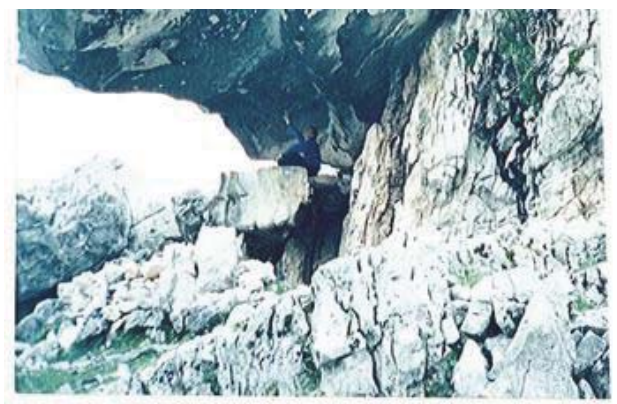

Figure 8. (Photo by A.Trushaj), Photo of "Written cave" Lepenice

In its roof there are 30 paintings made with mineral paint and brown color and the thickness of lines and figures of people is the geometrical length of $1-2 \mathrm{~cm}$ and width of the image in bigger size is $17 \times 9 \mathrm{~cm}$. Central place in rocky painting "In written cave" in Lepenica of Vlora city is based on anthropomorphic figures presented in schematic order and geometric figures (figure 9.a).

The head and the body is made of a thick line, while the limbs are made from two horizontal lines with limbs turn down, or completely closed, they maintain an orientation of establishing head west from the northwest (figure 9.b). Of the 30 paintings, 19 are anthropomorphic figures, and 11 geometrical figures.

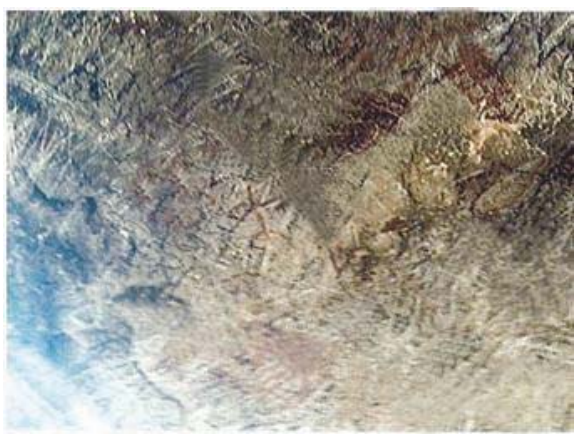

Figure 9.a. (Photo by A.Trushaj), Photo from pictures of Lepenica's cave 


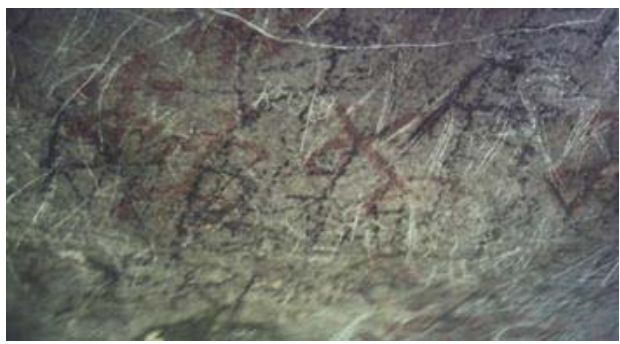

Figure 9.b. (Photo by A.Trushaj), Photo of anthropomorphic figures from Cave of Lepenice

Table.1: General drawings cave paintings in Lepenice

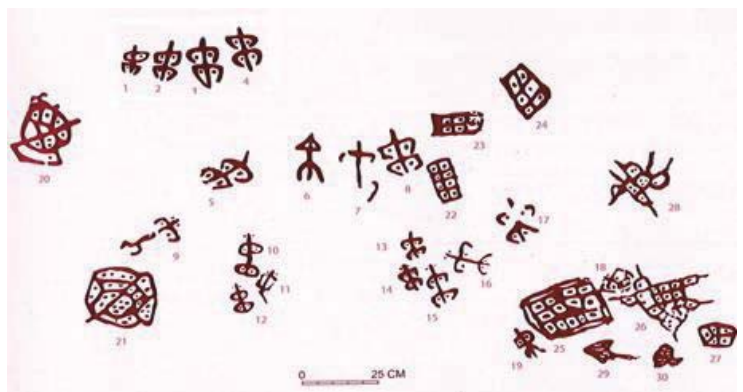

Note: Of the 30 paintings, 19 are anthropomorphic figures, and 11 geometrical figures.

Professor M. Korkuti accepted 8 regular geometric figures and a total of 27 paintings (M.Korkuti, ,Piktura shkëmbore e Lepenicës,, 1984) (M.Korkuti, ,Piktura shkëmbore e Lepenicës,, 1984). All anthropomorphic figures on the canvas to create four limbs have drawn from a point and seven of them are from a point on both sides of the head. Most of the figures are placed in the horizontal plane and only four anthropomorphic figures and two geometrical figures are in the vertical plane. Geometric shapes are irregular and limit anthropomorphic figures. Rectangular shaped images are divided into small squares with points in between. According M.Korkuti the usage of squares with point between also is witnessed of Rubik painting, the Tsogar, the Valcamonicas etc., "is interpreted as the source of life" (M.Korkuti, Arti shkembor ne Shqiperi,, 2008)(M.Korkuti, Arti shkembor ne Shqiperi,, 2008). The length of these figures ranges from $12 \mathrm{~cm}$ (the smallest) to $32 \mathrm{~cm}$ (the Longest). Surface painted of the ceiling shelter occupies an area of 2.40x1.40 m.

\section{What Do these Pictures Show and What's their Meaning?}

Assumptions are some: squares with points in between have to do with the economy, the main source of life of their reproduction. The highlights of the head side may indicate anthropomorphic figures about gender. The reading of Lepenica paintings should be seen and in another sense. Anthropomorphic figures give the impression that one is presented with hands on waist and knees sitting, before whom? Before geometric figures that for many primitive societies have imagined universe as a "divine liver" before which man felt inquisitive, powerless and scared.

Pictures of Lepenica is an image that relates abstract beliefs and their primary activity, the man testified that he was existing, believing and acting in order to convey in such monumental way in a form of message for the centuries coming next. Lepenice paintings based on analogies with other prehistoric paintings as those of Zlijebit in Bosnia, Puerto Badisco in Puglia, Levanzo north of Sicily etc., are the third millennium BC (the late Neolithic or early Eneolithic). Pictures of Lepenice must be the work of Neolithic inhabitants of Velça, where according to tradition the tribes went miles away outside the territory of their residence to process the sacred ceremony or dedications. The Distance from Velça cave in that of Lepenice normally is traversed on foot for 2.5-3 hours.

Two mountain peaks of Lungare to their dwellings (habitat), coated with high forest, were a better ground for hunting and for various religious ceremonies. 


\section{Concluding Remarks}

Vlora region includes all phases of archaeological development in the territory of Albania. This region has already documented and represents the only case in Albania where prehistory testified that in early stages of the Paleolithic epoch. The Paleolithic Stations of Xara, Saint Marenes and Konispol (Saranda), Gajtani (Skodra), containing archaeological matter of the mid and the later age, while the Palaeolithic station of Zverneci contains archaeological subject to lower Paleolithic, this is a particular case in Albanian prehistoric archeology. Velca Village area contains the largest complex of natural caves that are used for settlement of IV-th millennium B.C. It offers very good opportunities for further archaeological studies and better tourism opportunities.

In the territory of Vlora is the only megalithic monument, this is a special case in Albania, which has been used as a sanctuary altar from the residents of the area since the upper Shushice zone since prehistory. The prehistoric culture particularity in Vlora lies in the existence of prehistoric rock art paintings through which humans have tried to express symbolic complex meanings and creating complex thoughts.

Through these human has imagined, has believed, in vital primary activity, in heaven and earth. Lepenice paintings, is part of the group of post-Paleolithic rock paintings.

Surely, creator graphic language references, requires reading and further interpretations. Picture of Lepenice separates from all other paintings throughout Albania and in all Western Balkans to the complex character and its monumental. In Vlora territory there is no cultural gap, the period of identified metal is quite clear from the cemetery culture of small burial mound is testified in Vajze villages Dukat, Tragjas belonging to bronze-iron period.

But these are not a special case for this region, because burial mound culture is all over the territory of Albania and is distinguished for architectural similarities, materials and rituals. Vlora today constitutes the largest reservoir of archaeological wealth of the country.

\section{References}

Works Cited

C.Ptsch. (1904). Das sandschak Berat in Albanien, . Wien,: Wien,Austri.

D.Mustil. (1954-1955). Ricerche italiane per la preistoria dell'Albania,. Roma: Bull. Pal. Italiana, N.S.IX, 64,, p.407-408.

L.M.Ugolini, L. (1927). Albania Antica I, Ricerche archeologiche, . Roma-Milano, : Roma.

M.Korkuti. (1984). ,Piktura shkëmbore e Lepenicës,. "lliria"I , 10-20.

M.Korkuti. (2008). Arti shkembor ne Shqiperi,. Piktura e Lepenices , 18-29.

P.Treger. (1903). Archaologischer Anziger. Berlin : p.119. 